\title{
Tensile properties of cork in axial stress and influence of porosity, density, quality and radial position in the plank
}

\author{
Ofélia Anjos ${ }^{1,2,4^{*}}$, Helena Pereira ${ }^{2}$, M. Emília Rosa ${ }^{3}$ \\ ${ }^{1}$ Unidade Departamental de Silvicultura e Recursos Naturais, Escola Superior Agrária de \\ Castelo Branco, Apartado 119, 6001-909 Castelo Branco, Portugal \\ ${ }^{2}$ Centro de Estudos Florestais, Instituto Superior de Agronomia, Universidade Técnica de \\ Lisboa, 1349-017 Lisboa, Portugal \\ ${ }^{3}$ Departamento de Engenharia de Materiais, Instituto Superior Técnico, Universidade \\ Técnica de Lisboa, 1049-001 Lisboa, Portugal \\ ${ }^{4}$ CERNAS - Centro de estudos de recursos naturais, ambiente e sociedade, 3040-316, \\ Coimbra, Portugal
}

\section{*Corresponding author: E-mail: ofelia@esa.ipcb.pt}

\section{ABSTRACT}

The behaviour of cork under tensile stress in the axial direction was studied for samples taken from cork planks of good (class 1) and poor (class 4) quality grades and at three radial positions within the plank (inner, mid and outer positions). The effect of cork density (ranging from 0.123 to $0.203 \mathrm{~g} . \mathrm{cm}^{-3}$ ) and porosity (ranging from 2.8 to $9.6 \%$ in the tangential surface) on Young's modulus and fracture stress and strain was studied.

The tensile stress-strain curves of cork showed an elastic deformation up to $2 \%$ strain with a Young's modulus of $30.8 \mathrm{MPa}$, and a fracture stress of $1.05 \mathrm{MPa}$ at a strain of $7.1 \%$ for class 1 , and Young's modulus of $26.1 \mathrm{MPa}$, and a fracture stress of $0.77 \mathrm{MPa}$ at a strain of $5.5 \%$ for class 4 . Fracture always started at a pore. The quality class and the radial position in the plank were highly significant factors of the tensile properties variation with good quality cork in the inner part of the plank showing the highest strength.

Density influenced the elastic behaviour of cork with a highly significant correlation of increasing $E$ with density, but not so clearly the fracture stress and strain. The variability of tensile properties with porosity was large and although significant, the correlations were lower in spite of a decreasing trend of $E$ with porosity. Fracture depended on the type of defects in cork.

\section{Zugfestigkeitseigenschaften von Kork in axialer Richtung und Einfluss von Porosität, Dichte, Qualität und radiale Lage}

\section{Zusammenfassung}

Untersucht wurde das Verhalten von Kork unter Zugbelastung in axialer Richtung an Proben aus Rohmaterial der zwei Qualitätsklassen gut (Klasse 1) und schlecht (Klasse 4) und entnommen aus jeweils drei radialen Lagen (innen, Mitte und außen). Der Einfluss der Korkdichte (zwischen 0,123-0,203 g.cm $\mathrm{cm}^{-3}$ ) und der Porosität (zwischen 2,8 und 9,6\% in der tangentialen Oberfläche) auf den E-Modul und die Bruchspannung sowie Bruchdehnung wurden untersucht.

Die Spannungs-Dehnungskurven von Kork wiesen bei Zugbeanspruchung bei Proben der Klasse 1 bis zu 2\% Dehnung eine elastische Verformung mit einem E-Modul von 30,8 MPa auf, sowie eine Bruchspannung von 1,05 MPa bei einer Dehnung von 7,1\% und bei Klasse 4 Proben einen E-Modul von 26,1 MPa und eine Bruchspannung von 0,77 MPa bei einer Dehnung von 5,5\%. Der Bruch begann immer bei einer Pore. Die Qualitätsklasse und die radiale Lage waren stark signifikante Faktoren für die Variation der Zugeigenschaften, wobei Proben aus Kork guter Qualität aus dem Innenbereich die höchste Festigkeit aufwiesen. 
Die Dichte hatte Einfluss auf das elastische Verhalten von Kork, wobei die Korrelation mit dem E-Modul stark signifikant war. Die Korrelation mit Bruchspannung und Bruchdehnung war weniger ausgeprägt. Die Variabilität der Zugeigenschaften in Abhängigkeit der Porosität war groß. Die Korrelation war geringer signifikant, obwohl eine Abnahme des E-Moduls mit zunehmender Porosität erkennbar war. Der Bruch wurde von der Art des Holzfehlers im Kork beeinflusst.

\section{INTRODUCTION}

Worldwide, cork is known as the material used to make stoppers for wine bottles. It is a natural material that is obtained from the outer bark of the cork oak tree (Quercus suber). Cork has a cellular structure with small closed cells $\left(4-20 \times 10^{7}\right.$ cells $\left./ \mathrm{cm}^{3}\right)$ forming a highly ordered honeycomb with features that result from its biological process of formation (Graça and Pereira 2004, Pereira et al. 1987, Pereira 2007). The cell walls contain predominantly suberin in association with lignin and, to a lesser extent, cellulose and hemicelluloses (Pereira 1988).

Cork shows an interesting group of properties by combining low values of density, permeability and energy transfer coefficients with a considerable elastic behaviour and high physical, chemical and biological stability (Pereira 2007).

The mechanical properties of cork were studied mostly in compression, due to its relevance for the performance of cork stoppers in wine bottling and sealing (Rosa and Fortes 1988, Gibson et al. 1981, Gibson and Ashby 1997). The behaviour of cork under tensile stress is very much less documented. It is known that under tension, the cell walls become straighter and aligned in the stress direction, and that further deformation occurs by stretching of walls until fracture (Rosa and Fortes 1991). Cork is put under tensile stress when a stopper is pulled out of a wine bottle; in this case the load is applied in the axial direction of the cork. In the tree, the cork layers are also put under tension by the radial growth of the stem (Fortes and Rosa 1992) but in this case the load is applied tangentially. Fracture may occur in both cases.

The tensile behaviour of cellular materials depends on the homogeneity of the structure and is very sensitive to the presence of defects. For instance, the random removing of cell walls has a dramatic effect on the stiffness and strength of honeycombs and foams (Albuquerque et al. 1999), and $10 \%$ removal of struts reduces the modulus and strength of a honeycomb by about $60-70 \%$ (Chen et al. 1999, Vajjhala et al. 2000).

Cork is not completely homogeneous and therefore its mechanical behaviour will depend on the specific particularities of the structure, namely porosity and ligneous inclusions or cracks. Cork has lenticular channels crossing the cork planks in a radial direction that appear in the tangential section as pores with a more or less circular form filled with a material of loosely bound cells with different chemical composition, and occasionally lined by heavily lignified cells (Pereira et al. 1996, Pereira 2007). This porosity is a conspicuous feature of cork and the main quality parameter used to grade cork. The cork tissue may also contain occasional defects such as spots of sclerenchymatic cells with thick lignified walls, or inclusions of phloemic tissues, as well as tissue failures making up radial running hollow channels.

In compression, the properties of cork were found to vary with density, cellular dimensions and porosity (Gibson and Ashby 1997, Pereira et al. 1992, Anjos et al. 2008). The influence of these effects was not studied in relation to the tensile properties.

This is the aim of the present study where the behaviour of cork under tension was characterized using stress-strain curves, and the influence of porosity, density and commercial quality of cork planks on the Young's modulus and fracture resistance was analysed. Since porosity and density of cork vary within the cork plank from the inside to the outside (Pereira 2007), the influence of the radial position in the plank on the tensile properties of cork was also studied.

\section{MATERIAL AND METHODS}


The cork specimens were prepared from raw cork planks collected at one industrial mill after six-month of air stabilization. Four planks of good quality (class 1 ) and four planks of poor quality (class 4) were taken after the usual industrial pre-processing consisting of a 1-h water boiling operation and air drying.

The test specimens were cut from each cork plank as plates with the dimensions $30 \mathrm{~mm} \times 5$ $\mathrm{mm} \times 100 \mathrm{~mm}$ in the tangential, radial and axial directions, respectively. Samples were taken in three radial positions in the cork planks: in the inner part (the belly side of the plank located to the inner part of the stem), in the outer part (the back side) and in mid position. The specimens were equilibrated in laboratorial environment to $7 \%$ mean moisture content, then weighed and the density was calculated.

The tensile test used a crosshead speed of $5 \mathrm{~mm} \mathrm{~min}^{-1}$, corresponding to a strain rate of 1.4 $\times 10^{-3} \mathrm{~s}^{-1}$ applied in the axial direction. The samples were fixed to two aluminium grip plates to which the stress was applied leaving free sample length between grips of $60 \mathrm{~mm}$ (Fig. 1). Young's modulus was calculated from the average slope of the stress-strain curve between the loads of $10 \mathrm{~N}$ and $100 \mathrm{~N}$, corresponding to strains between approximately $1 \%$ and $2.5 \%$.

The porosity of the specimen plates was determined prior to the tensile tests by image analysis on the two tangential surfaces parallel to the direction of the tensile stress. The image was acquired at a 10X magnification using a color video camera (3CCD) and analyzed with the Pericolor-Matra software using image analysis and mathematical morphology methodological tools (Soile 1995). The porosity was reported as a coefficient of porosity, in $\%$, representing the area of pores divided by the total area, and calculated as the mean of the two faces measured in each sample. The following pore characteristics were also determined: number of pores per unit area (number $\left./ \mathrm{cm}^{2}\right)$, distance to the nearest pore, pore irregularity (ratio between real perimeter and the convex perimeter, i.e., the regular perimeter that include the entire irregular pore perimeter) and elongation (ratio between the largest and smallest pore axis).

The results were statistically analysed by analysis of variance using as fixed variation effects the quality class and the radial position in the plank, and their interaction, and by principal component analysis.

\section{RESULTS AND DISCUSSION}

The tensile behaviour of the cork samples is represented in Fig. 2 by the stress-strain curves up to fracture, for tension applied in the axial direction, as the mean values for each of the three radial positions and the two cork plank quality grades.

The curves show an initial linear elastic region approximately until $2 \%$ strain and $0.4 \mathrm{MPa}$ stress, with $28 \mathrm{MPa}$ mean Young's modulus, followed by a region of decreasing slope corresponding to a gradual cork yielding up to a peak load, after which almost immediately a near complete failure across the section occurs. A decrease of stress after the peak load until fracture was not observed. Fracture occurred at an average stress of $1 \mathrm{MPa}$ and $7 \%$ strain. This behaviour is common to cellular materials and follows the previously described tensile behaviour of cork (Rosa and Fortes 1991, Gibson and Ashby 1997).

Cork has substantially higher elastic resistance in tensile that in compression (Anjos et al. 2008; Gibson and Ashby 1997). This difference can be explained because the cork cell walls are undulated plates (Pereira et al. 1987, Gibson et al. 1981).and the stiffness of undulated plates increases when the amplitude of the undulations decreases Therefore, in compression the walls bend and increase the cell wall corrugation, while in tension the cells are stretched and the cell wall undulations decrease (Anjos et al. 2008, Rosa and Fortes 1991).

\section{Influence of density}

Density influences the mechanical properties of cellular materials (Gibson and Ashby 1997). In cork, density varies with the cell geometry, the cell wall undulation and the presence of lenticular channels or other discontinuities (Anjos et al. 2008, Rosa and Fortes 1988). Cork density influenced the compressive properties and its elastic behaviour could be modelled using density as a variable (Anjos et al. 2008, Gibson and Ashby 1997).

The densities of the cork samples used in the tensile tests ranged from 0.148 to $0.178 \mathrm{~g} . \mathrm{cm}^{-}$

${ }^{3}$. Fig 3 shows the variation of the Young's modulus $(E)$, fracture stress $(\sigma)$ and fracture strain 
$(\varepsilon)$ with density for the tensile tests of all the cork samples. There was a trend of increasing $E$ with density $(R=0.722, P=0.000)$, although the variability was larger for the higher values of Young's moduli and densities. The fracture strain showed a slight trend of increase with density $(R=0.313, P=0.007)$ but the variability was large, while the fracture stress showed no significant correlation with density $(R=0.214, P=0.071)$.

Fracture parameters were not directly related with density because fracture is more affected by stress concentrators such as pores or other defects and these may either increase or decrease the density depending on their type and structure.

Influence of porosity

The porosity of the tested cork samples varied from $2.8 \%$ to $9.6 \%$. Fig. 4 shows the variation of the Young's modulus, fracture stress and strain with the porosity measured on the tangential faces parallel to the tensile stress. The correlations were not very large although highly significant: Young's modulus decreased with porosity $(R=0.483, P=0.001)$, the fracture strain decreased $(R=0.500, P=0.000)$ while the fracture stress increased $(R=0.466$, $\mathrm{P}=0.000$ ).

The effect of porosity and density in the cork tensile properties was not as evident as the one reported for compression (Anjos et al. 2008). This can be explained by the fact that the tensile behaviour has a large dependence on the structural defects of the material in relation to their type and dimensions. In cork the defects vary in kind, i.e., pores, cracks or notches and show different types of cells such as lenticular filling cells and thick walled lignified cells (Gonzalez-Adrados and Pereira 1996). Since the occurrence of these defects and their distribution present a large variability between cork samples, it is difficult to predict the tensile behaviour of cork namely the fracture.

\section{Fracture}

The fracture occurred across the section of the cork specimens, approximately perpendicular to the direction of the tensile load. The fracture started always at the pores, at the defect with the highest tensile stress concentration, and the direction of propagation could change by the presence of spots with different resistance such as pores with sclerenchymatic cells (Fig. 5). The presence of sclerified cells in the cork tissue without being associated to the pores did not influence the fracture resistance, but could influence its propagation. The fracture started always at a pore but when the fracture propagated between two pores, it avoided the regions with greater resistance.

At the cellular level, the fracture usually propagated along the lateral cell walls by the middle lamella between cells as previously reported (Rosa and Fortes 1991), but it was sometimes possible to observe fracture across the cells (Fig. 6).

\section{Influence of cork plank quality}

When comparing quality grades (Fig. 2), it can be observed that although the tensile behaviour of cork is similar for both grades as regards the development of the stress-strain curves, the specimens from the poor quality plank (class 4) generally showed lower stress values for the same strains, and smaller values for the stress and strain at fracture. For class 1 cork the mean values were $30.8 \mathrm{MPa}$ for the Young's modulus, $1.05 \mathrm{MPa}$ fracture stress at a strain of $7.1 \%$, while for class 4 cork the values were $26.1 \mathrm{MPa}, 0.77 \mathrm{MPa}$ and $5.5 \%$, respectively.

The differences between the cork samples from class 1 and class 4 were statistically significant. They are related to the different porosity features observed in the samples obtained from the two quality classes of cork planks. As seen in Table 1, class 1 corks had significantly lower porosity and number of pores, and a higher mean distance to the nearest pore.

\section{Influence of radial position}

Table 2 indicates the mean values of Young's moduli and stress and strain at fracture for the two plank quality grades and for the three radial positions within the planks. The stress-strain 
curves for the specimens taken in the three radial positions within the plank showed a similar development, and in the case of the inner and mid positions also similar resistance values. However the specimens taken from the outer position in the cork plank have somewhat different resistance, lower in the case of good quality planks, higher in poor quality planks.

The difference shown by the cork specimens taken at the three radial positions in the plank is the result of the radial variation which is observed regarding porosity, density and cell dimensions (Table 2).

Density is higher in the inner part of the plank, e.g., on average $0.175 \mathrm{~g} \mathrm{~cm}^{-3}$ and $0.156 \mathrm{~g} \mathrm{~cm}^{-}$ ${ }^{3}$, respectively in the inner and outer positions. This results from the fact that the annual rings of cork have decreasing width towards the inner part of the plank (Ferreira et al. 2000, Fortes and Rosa 1992). Thinner rings have a relatively larger proportion of latecork cells with thicker cell walls and smaller radial dimension (Pereira et al. 1987), and thereby lead to larger values of density (Fortes and Rosa 1992). On the contrary, the wider annual rings in the outermost part of the cork plank contain cells with larger mean dimensions (Pereira et al. 1992).

Porosity decreased radially in the plank from the outer part to the inner part: $4.1 \%$ and $7.1 \%$ in the inner and outer positions, respectively. Overall it is also observed that there are usually less defects in the inner part of the plank, and this is the reason why wine stoppers are bored as close as possible to the inner part of the cork plank (Pereira 2007).

These characteristics of the cork in the inner part of the plank, i.e., a structure with smaller cells with thicker walls and a smaller content of defects, explain why it presented higher tensile elastic and fracture resistance (Table 1).

\section{Statistical analysis}

The variance analysis revealed that the quality grade and the radial position in the plank were very significant factors of variation of the Young's modulus, corresponding to $25 \%$ and $22 \%$ of the total variance. The interaction between quality class and radial position explained $30 \%$ of the total variance, as a result of the different behaviour observed in class 1 and class 4 along the radial direction (Table 1).

For fracture stress and strain, the quality class explained a higher proportion of the total variance $(49 \%$ and $39 \%$, respectively) but the unexplained variability was large (residual value of $25 \%$ and $40 \%$, respectively). This confirms the fact that fracture is more dependent on the type or position of the pores which may constitute points with higher stress concentration.

Principal components analysis showed that the first component explains $46.1 \%$ of the total variation and includes a series of properties, with the highest correlation for tensile parameters, density and distance to the nearest pore, as well as porosity and number of pores but in inverse order, while the second component explained only $14.5 \%$ of the total variation and includes mostly form factors of pores (irregularity and elongation). Separation of samples by quality and position in the plank was not fully achieved. This type of difficulty of using statistical analysis to classify cork was already observed in relation to the quality of cork planks and stoppers (Costa and Pereira 2006, Gonzalez-Adrados et al. 2000).

\section{CONCLUSION}

The tensile properties of cork, namely fracture stress and strain, depend on the irregularities that are present in the cork structure and their specific characteristics. Fracture starts at a pore and propagation depends on the occurring defects. The elastic behaviour is related to the density and, to a lesser degree, to the coefficient of porosity. In comparison to compression, cork under tension is more resistant and has a smaller elastic strain.

The tensile properties of cork vary in the plank from the inner part to the outer part, with a trend of decreasing strength, and also vary with the cork plank quality, with higher tensile strength for good quality corks.

\section{ACKNOWLEDGEMENTS}


We thank Subercentro Cortiças, Lda. in Ponte de Sor, Portugal, for the cork planks and Pedro Pina for his help to develop the image analysis algorithm.

\section{References}

Albuquerque JM, Fátima Vaz M, Fortes MA (1999) Effect of missing walls on the compression behaviour of honeycombs. Scripta Materialia 41(2):167-174.

Anjos O, Pereira H, Rosa ME (2008) Effect of quality, porosity and density on the compression properties of cork. Holz Roh- Werkst 66(4): 295-301.

Chen C, Lu T. J., Fleck N. A. (1999) Effect of imperfections on the yielding of twodimensional foams, Journal of the Mechanics and Physics of Solids. 47(11): 2235-2272

Ferreira A, Lopes F, Pereira H (2000) Caractérisation de la croissance et de la qualité du liège dans une région de production" Annal. Sci. For. 57:187-193.

Fortes MA, Rosa ME (1992) Growth stress and strains in cork. Wood Sci Technol 26: 241258

Costa A, Pereira H (2006) Decision rules for computer vision quality classification of wine natural cork stoppers. American Journal of Enology and Viticulture. 57(2):210-219.

Gibson LJ, Ashby MF (1997) Cellular Solids - Structure and properties, $2^{\text {nd }}$ Edn. Cambridge University Press, Cambridge

Gibson LJ, Easterling KE, Ashby MF (1981) The structure and mechanics of cork. Proceedings Royal Society London A 377: 99-117

Gonzalez-Adrados J, Pereira H (1996) Classification of defects in cork planks using image analysis. Wood Sci Technol 30(3): 207-215.

Gonzalez-Adrados JR, Lopes F, Pereira H (2000) Quality grading of cork planks with classification models based on defect characterisation. Holz Roh- Werkst 58(1-2): 39-45.

Graça J, Pereira H (2004). The periderm development in Quercus suber. IAWA Journal, 25 (3): 325-335.

Pereira H (1988). Chemical composition and variability of cork form Quercus suber L. Wood Sci Technol 22(3): 211-218.

Pereira H (2007) Cork: Biology, Production and Uses. Elsevier Publications, Amsterdam, 336 pp.

Pereira H, Graça J, Baptista C (1992) The effect of growth rate on the structure and compressive properties of cork. IAWA Bulletin 13(4): 389-396.

Pereira H, Lopes F, Graça J (1996) The evaluation of the quality of cork planks by image analysis. Holzforschung 50(2): 111-115.

Pereira H, Rosa ME, Fortes MA (1987) The cellular structure of cork from Quercus suber L. IAWA Bulletin 8(3):213-218 
Pina P, Fortes MA (1996) Characterization of cells in cork. Journal Applied Physics D, 29: 2507-2514

Rosa ME, Fortes MA (1988) Cork density: influencing factors (in Portuguese) Cortiça 593:6569.

Rosa ME, Fortes MA (1991) Deformation and fracture of cork in tension. Journal of Materials Science 26(2): 341-348

Soile P (1995) Morphological image analysis. Principles and applications. Springer Verlag, Berlin

Vajjhala S, Kraynik AM, Gibson LJ (2000) A cellular model for modulus reduction due to resorption of trabeculae in bone. Journal of Biomechanics 122:511-515. 
Tabelle 1

Dichte und Porosität (Porositätskoeffizient, Anzahl der Poren, Abstand zur nächsten Pore) der für die Zugprüfungen verwendeten Korkprüfkörper aus Rohmaterial unterschiedlicher handelsüblicher Qualität (Klasse 1: gut und Klasse 4: schlecht). Die Zugbelastung erfolgte in axialer Richtung; die Porosität wurde auf tangentialen Flächen der Proben gemessen.

Mittelwert von 12 Prüfkörpern und Standardabweichung.

Tabelle 2

Zugfestigkeitseigenschaften der Prüfkörper aus Rohmaterial verschiedener handelsüblicher Qualität (Klasse 1: gut und Klasse 4: schlecht) und in drei radialen Lagen (innen, Mitte und außen). Die Zugbelastung erfolgte in axialer Richtung. Mittelwert von 12 Proben und Standardabweichung

Abb. 1

Schematische Darstellung des Zugprüfkörper einschließlich der Aluminiumhalterung und der Prüfkörperabmessungen

Abb. 2

Spannungs-Dehnungs-Kurven axial zugbeanspruchter Korkprüfkörper in Abhängigkeit der Qualitätsklassen ((Klasse 1: gut und Klasse 4: schlecht) und der Lage in radialer Richtung (innen, Mitte, außen).

Abb. 3

E-Modul (A), Bruchspannung (B) und Bruchdehnung (C) in Abhängigkeit der Korkdichte bei axialer Zugbeanspruchung

Abb. 4

E-Modul (A), Bruchspannung (B) und Bruchdehnung (C) in Abhängigkeit der Korkporosität bei axialer Zugbeanspruchung

Abb. 5

Bruchfortschritt in Kork unter axialer Zugspannung

Abb. 6

Bruch im Korkprüfkörper quer durch die Zellwände unter Zugspannung. 
Table 1. Density and porosity characteristics (coefficient of porosity, number of pores, distance to nearest pore) of the cork specimens used in the tensile tests obtained from cork planks of different commercial quality (class 1 and class 4, respectively good and poor). The tensile load was applied in the longitudinal direction of the samples; the porosity was measured on the tangential sections of the samples. Mean of twelve samples and standard deviation.

\begin{tabular}{cccccc}
\hline $\begin{array}{c}\text { Cork } \\
\text { plank } \\
\text { quality }\end{array}$ & $\begin{array}{c}\text { Radial } \\
\text { position } \\
\text { in plank }\end{array}$ & $\begin{array}{c}\text { Density } \\
\left(\mathbf{g ~ c m}^{-3}\right)\end{array}$ & $\begin{array}{c}\text { Porosity } \\
\mathbf{( \% )}\end{array}$ & $\begin{array}{c}\text { Number of } \\
\text { pores per } \\
\mathbf{c m}^{2}\end{array}$ & $\begin{array}{c}\text { Distance } \\
\text { to nearest } \\
\text { pore }(\mathbf{c m})\end{array}$ \\
\hline \multirow{3}{*}{ Class 1 } & inner & $0.178 \pm 0.010$ & $3.51 \pm 0.41$ & $6.8 \pm 1.0$ & $0.24 \pm 0.03$ \\
& mid & $0.169 \pm 0.007$ & $5.22 \pm 0.63$ & $6.6 \pm 1.4$ & $0.23 \pm 0.02$ \\
& outer & $0.152 \pm 0.005$ & $6.35 \pm 0.79$ & $8.6 \pm 0.9$ & $0.21 \pm 0.01$ \\
\hline \multirow{3}{*}{ Class 4 } & inner & $0.171 \pm 0.012$ & $4.67 \pm 1.15$ & $8.3 \pm 1.1$ & $0.21 \pm 0.02$ \\
& mid & $0.148 \pm 0.011$ & $5.76 \pm 1.23$ & $9.0 \pm 0.7$ & $0.21 \pm 0.01$ \\
& outer & $0.160 \pm 0.015$ & $7.80 \pm 0.64$ & $9.6 \pm 1.0$ & $0.20 \pm 0.01$ \\
\hline
\end{tabular}

Table 2. Tensile properties of cork specimens obtained from cork planks of different commercial quality (class 1 and class 4 , respectively good and poor) and at three radial positions within the plank (inner, mid and outer part). The tensile load was applied in the longitudinal direction of the samples. Mean of twelve samples and standard deviation

\begin{tabular}{llccc}
\hline $\begin{array}{l}\text { Cork plank } \\
\text { quality }\end{array}$ & $\begin{array}{c}\text { Tensile } \\
\text { properties }\end{array}$ & inner & mid & outer \\
\hline \multirow{3}{*}{ Class 1 } & $\mathrm{E}(\mathrm{MPa})$ & $35.3 \pm 1.48$ & $31.7 \pm 2.35$ & $25.4 \pm 3.17$ \\
& $\sigma_{\mathrm{f}}(\mathrm{MPa})$ & $1.27 \pm 0.07$ & $1.00 \pm 0.12$ & $0.89 \pm 0.15$ \\
& $\varepsilon_{\mathrm{f}}(\%)$ & $8.22 \pm 0.68$ & $6.27 \pm 1.36$ & $6.89 \pm 1.0$ \\
\hline \multirow{3}{*}{ Class 4 } & $\mathrm{E}(\mathrm{MPa})$ & $28.75 \pm 3.88$ & $22.87 \pm 4.50$ & $36.65 \pm 3.18$ \\
& $\sigma_{\mathrm{f}}(\mathrm{MPa})$ & $0.83 \pm 0.23$ & $0.75 \pm 0.13$ & $0.73 \pm 0.10$ \\
& $\varepsilon_{\mathrm{f}}(\%)$ & $5.72 \pm 1.49$ & $5.79 \pm 0.98$ & $4.98 \pm 1.11$ \\
\hline \multicolumn{4}{l}{ Young's modulus $(\mathrm{E})$, fracture stress $\left(\sigma_{\mathrm{f}}\right)$, fracture strain $\left(\varepsilon_{\mathrm{f}}\right)$}
\end{tabular}




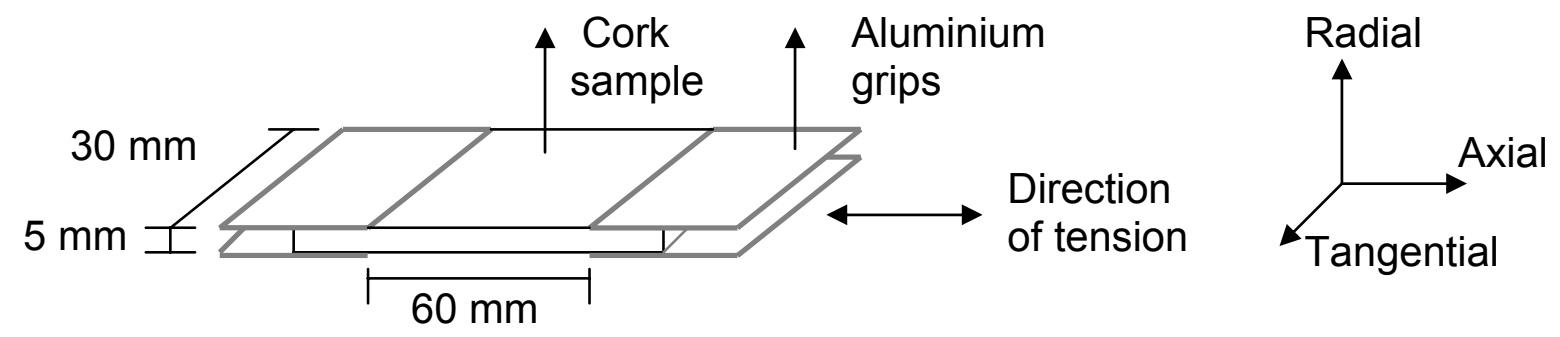

Figure 1. Schematic diagram of the configuration of the tensile test with location of the aluminium plate grips and sample dimensions 

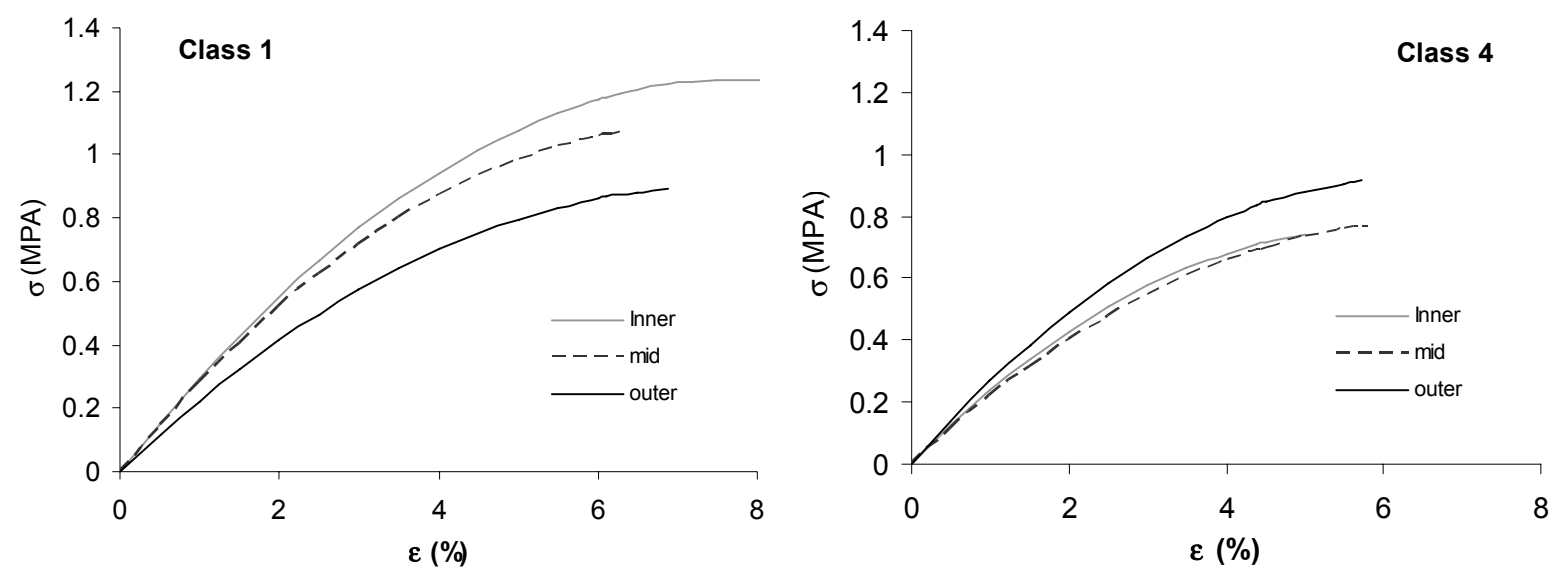

Figure 2. Stress-strain curves for tension of cork specimens along the axial direction obtained from cork planks of different commercial quality (class 1 and class 4 , respectively good and poor quality) in three radial positions within the cork plank (inner, mid and outer)

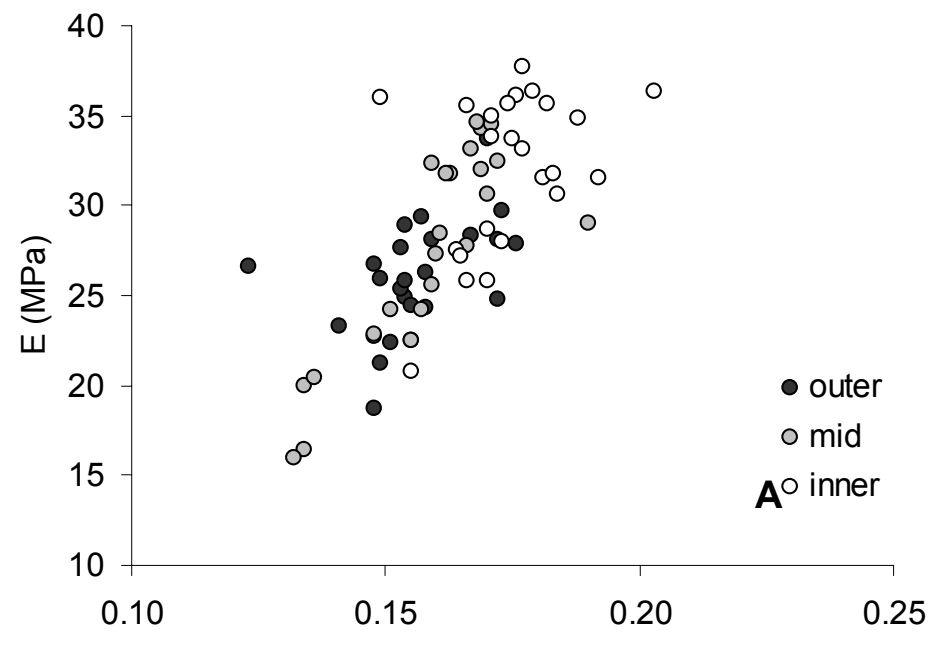



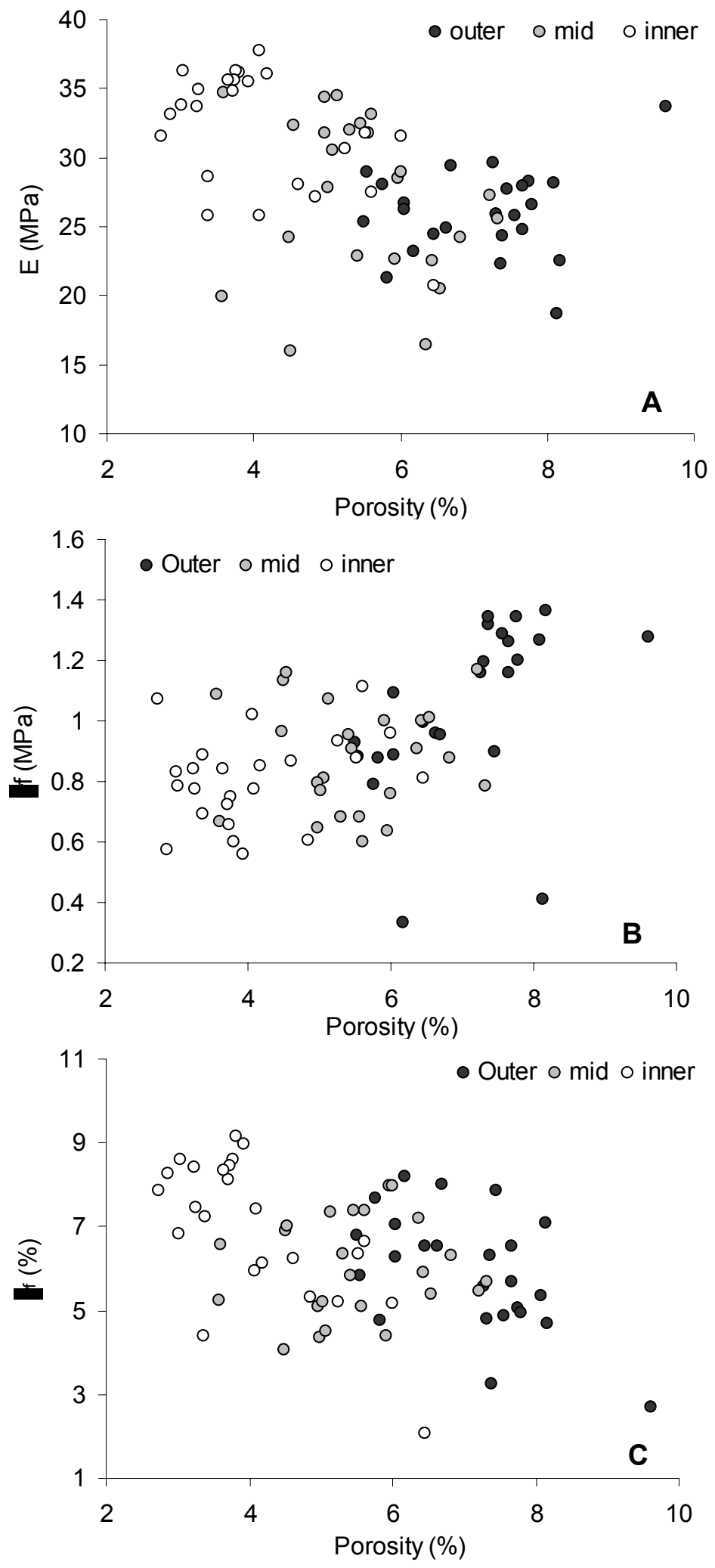

Figure 4 - Variation of the Young's modulus (A), fracture Stress (B) and fracture strain (C) in axial tension with cork porosity. 


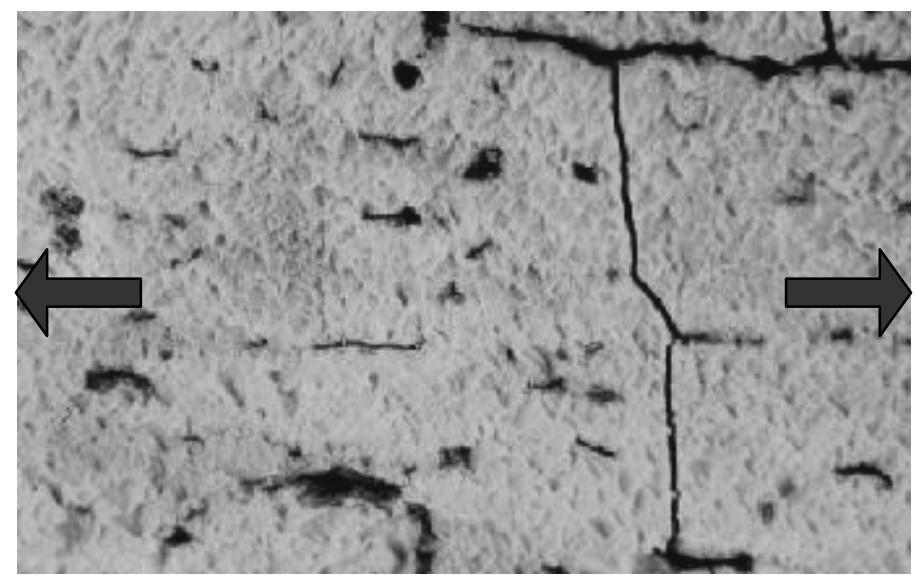

Figure 5. Fracture propagation in cork stressed in axial tension.

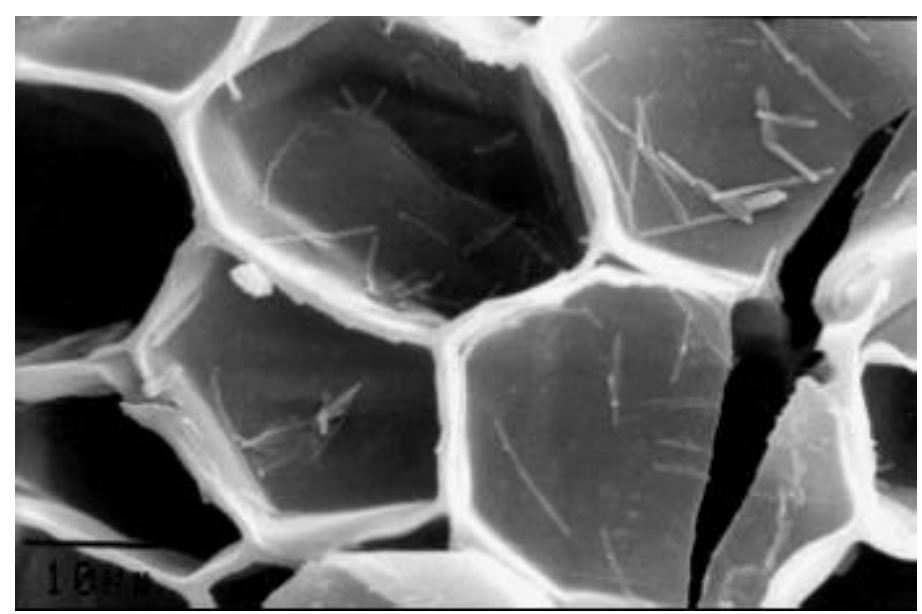

Figure 6. Fracture across the cell walls caused by an axial stress seen in the tangential section of cork. 